Journal of Physics and Its Applications

Journal homepage: https://ejournal2.undip.ac.id/index.php/jpa/index

\title{
Characterization of Landslide geometry using Seismic Refraction Tomography in the GayoLues, Indonesia
}

\author{
Muzakir Zainal ${ }^{*}$, Badrul Muniri,2, Marwan ${ }^{1}$, Muhammad Yanis ${ }^{1}$, Akmal Muhni ${ }^{3}$ \\ ${ }^{1}$ Department of Geophysical Engineering, Faculty of Engineering, UniversitasSyiah Kuala, Banda Aceh, Indonesia \\ ${ }^{2}$ Graduate School of Physics, Faculty of Mathematics and Natural Sciences, UniversitasSyiah Kuala, Banda Aceh, Indonesia \\ ${ }^{3}$ Department of Geological Engineering, Faculty of Engineering, UniversitasSyiah Kuala, Banda Aceh, Indonesia
}

*)Corresponding author: muzakirzainal@unsyiah.ac.id

\section{A R T I C L E IN F O}

\section{Article history:}

Received: 14 March 2021

Accepted: 30 April 2021

Available online: 28 May 2021

\section{Keywords:}

Seismic refraction

Landslide

Debris Flow

Disaster Mitigation

Aceh Province

\begin{abstract}
A B S T R A C T
Landslides are the most common geological phenomenon in Indonesia.The event is damage to public infrastructure, and fatalities was a big impact. Therefore, mapping the geometry of landslides is a part of the mitigation effort possible by geophysical methods. In this research, we applied seismic refraction tomography (SRT) to study the geometry of the sliding zone from the landslide event.TheNational Disaster Management Authority reported that the area was frequently occurring landslide disaster, i.e. 2018, 2019 and 2020 which caused the public infrastructure and obstructed the road access from the central to the west of Aceh. The SRT was measured in two profileslong the road.Data measurements were conducted on the side of the Babahrot - GayoLues road section that had experienced landslides.Measurements were made using the Seismograph PASI 16S24-P and 24 geophones to obtain a 92 -meterlong profile with 2 meter spacing between the geophones. P-wave velocity data modeling is done using ZondST2D software.The results of modeling profiles 1 and 2 describe three different subsurface layers.The SRT profile 1 model consists of slate $(0.2-0.7$ $\mathrm{km} / \mathrm{s})$, clay $(0.8-1.3 \mathrm{~km} / \mathrm{s})$, and sandy clay $(1.4-1.9 \mathrm{~km} / \mathrm{s})$.While, the model of profile 2 consists of slate $(0.5-1.0 \mathrm{~km} / \mathrm{s})$, clay $(1.1-1.6 \mathrm{~km} / \mathrm{s})$, and sandy clay $(1.7-2.5 \mathrm{~km} / \mathrm{s})$.The contrasting wave velocity model shows that the SRT method can be used in landslide studies as a reference in determining the mechanism of the landslide system.
\end{abstract}

\section{Introduction}

The landslideeventsis one of the frequenlynatural disasters and has a significantimpact in Indonesia, specially in the high rain intensity[1-2]. Meanwhile, it also impacts the destruction of infrastructure and disconnection of transportation modes which significantly affect economic activity [3-4]. Aceh Province is an area that geographically has conditions in a tropical climate with high rainfall and steep topography and vulnerable to earthquakes, which are the primarytriggers for landslides [5]. According to National Disaster Mitigation Agency, the landslide phenomena has been occur the 355 landslide in 2019 and 473 in 2018 that have been reported in Indonesia. Besides, in 2020 the period from January to June has recorded 36 cases of disasters, One area in Aceh that has the potential for large landslides is GayoLues Regency [6].

The Digital Elevation Model data analysis (Fig. 1) shows the area is located on the high slope, thus making the area frequent landslides. The GayoLues Babahrot road section is one of the public infrastructure facilities in the Blangkejeren, GayoLues Regency, which has suffered a significantimpact from the landslide. This road section is the only access point from Southwest Aceh
Regency - GayoLues Regency. Looking at existing data shows that the area has a high potential for disaster. Furthermore, the mitigation effortsis needed to minimize the disaster impact in the future, and casuality dead may be avoided. So, more of studies that focused on the landslide disaster are needed.

Disaster mitigation studies can be carried out in various disciplines. Among them issatelliteimagery for mapping on a wide scale and slope characteristics [7]. However, this study could not provide information relating to the condition of the landslide, which has complex geological conditions and physical properties of the subsurface that contrasts[8]. Characteristics of complex subsurface geometries in landslide areas require a study on a local scale to obtain detailed features. Several scientific studies can be used, such as geomorphological studies that determine landslides' potential based on landscape conditions and slope [9]. Geotechnical studies that determine the potential for landslides are based on an analysis of the slope and the physical properties of the surrounding rocks [10-11]. However, this study has not provided detailed subsurface information as a basis for determining subsurface geometric 
characteristics. Geophysical studies have become applications that have been widely used in subsurface studies, especially those related to landslides. This is due to the ability of these methods to provide accurate and fast subsurface information [12-13].

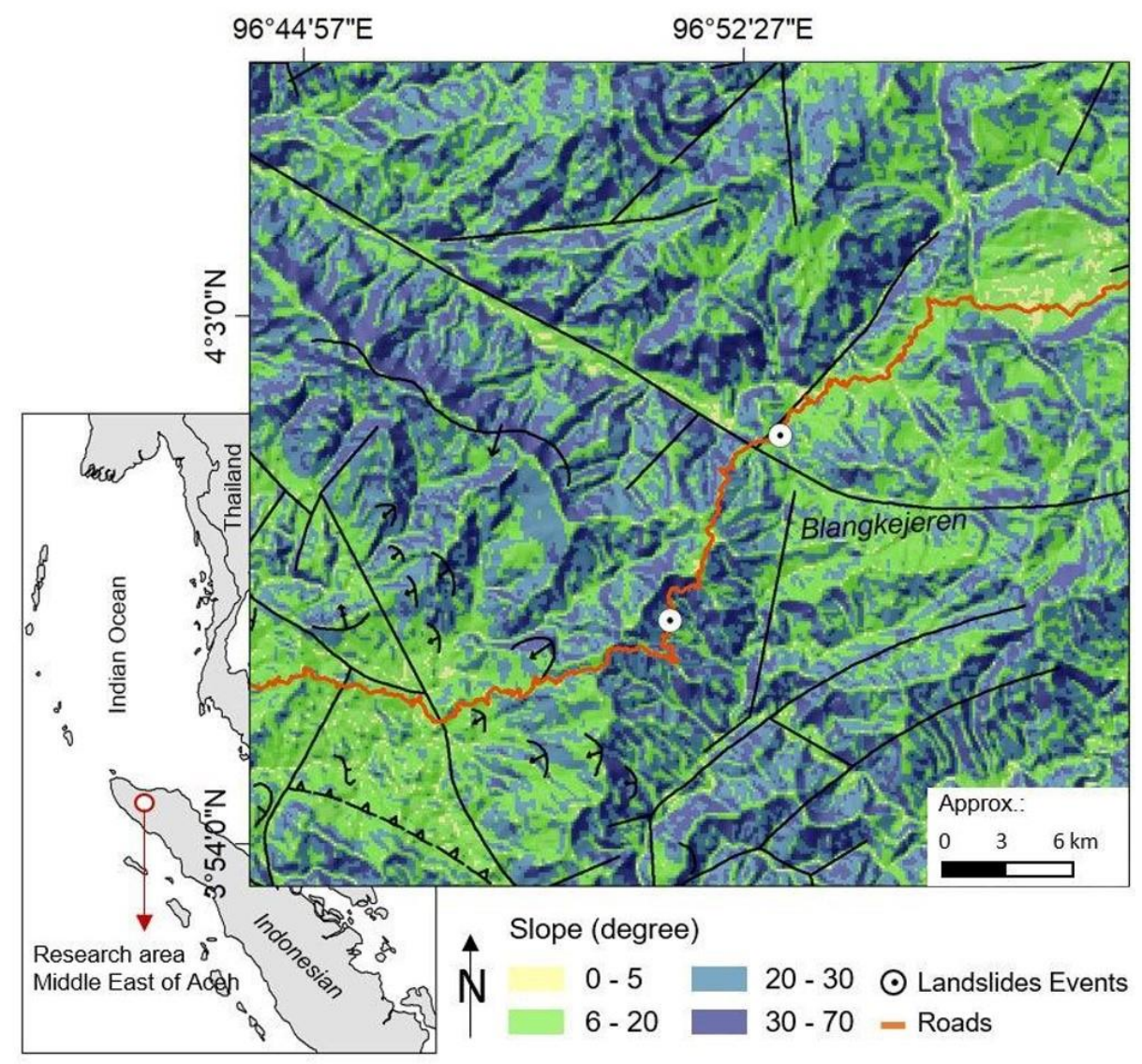

Fig.1:Analysis of slope data by using DEM 30 meters in the central part of Aceh Province. The area is characterized by a high slope that may occur a potential landslide.

The application of near-surface geophysical methods has been successfully applied in several cases, such as the application of electromagnetic methods for delineation of sedimentary material boundaries in detail on paleochannel areas in Aceh[14], mapping of the archaeological prospecting of the KutaLubok site from the ancient Tsunami [15] and specifically also applied to landslide applications in South Aceh [16]. Mapping of the determination of the depth of the aquifer layer in hydrogeological studies using the resistivity method [17-18] and near-surface fault studies [19]. The applications of electrical resistivity also have been conducted in the same site of the research area. The 2D model of resistivity data shows the geometrical landslides boundary into three layers; slate, clay, and sandy clay.Based on the distribution of the subsurface resistivity constrained to porosity and groundwater, which are the main components of landslides[20]. Besides, studies using seismic methods have been widely applied. Among them is the determination of the weak zone in the manifestation area of IeJue, Aceh Besar[21], landslide hazards in the United Kingdom[22], and Hangzhou, China [23].

Generally, the study area is dominated by alluvium and colluvium (Fig. 2). The presence of sedimentary rocks also dominates, including sandstone, mudstone, siltstone, shale, tuff, and schist. Besides, there are also igneous rocks with granite,
Other refractive seismic studies have shown that P-wave parameters are sensitive to lithological conditions with high porosity and fluid content. Simultaneously, the S-wave cannot provide a significant difference in the porosity of watersaturated or dry rock porosity. Hence, the SRT method is a commonly used application for landslide studies [24-25]. Therefore, we use the P-wave parameter to delineate the landslide geometry at Blangkejeren, GayoLues districts.

\section{Study Area and Geological Settings}

The study area is in the central part of Aceh Province (Fig. 2), located along the active Great Sumatran Fault (GSF), which has high tectonic activity [26]. Tectonic activity from the existence of a subduction zone at the confluence of the Indo-Australian and Eurasian plates on the southern side of Sumatra, resulting in local faults [27-28]. The tectonic activity of the GSF is one of the triggers for landslides in West Sumatra [29]. Besides, this tectonic activity plays an essential role in producing topographic conditions with slopes of $\pm 45^{\circ}$ and various rock distributions in the site.

granodiorite, and rhyolite distributed around the area. Conditions that are dominated by alluvium sediments increase the potential for landslides. 


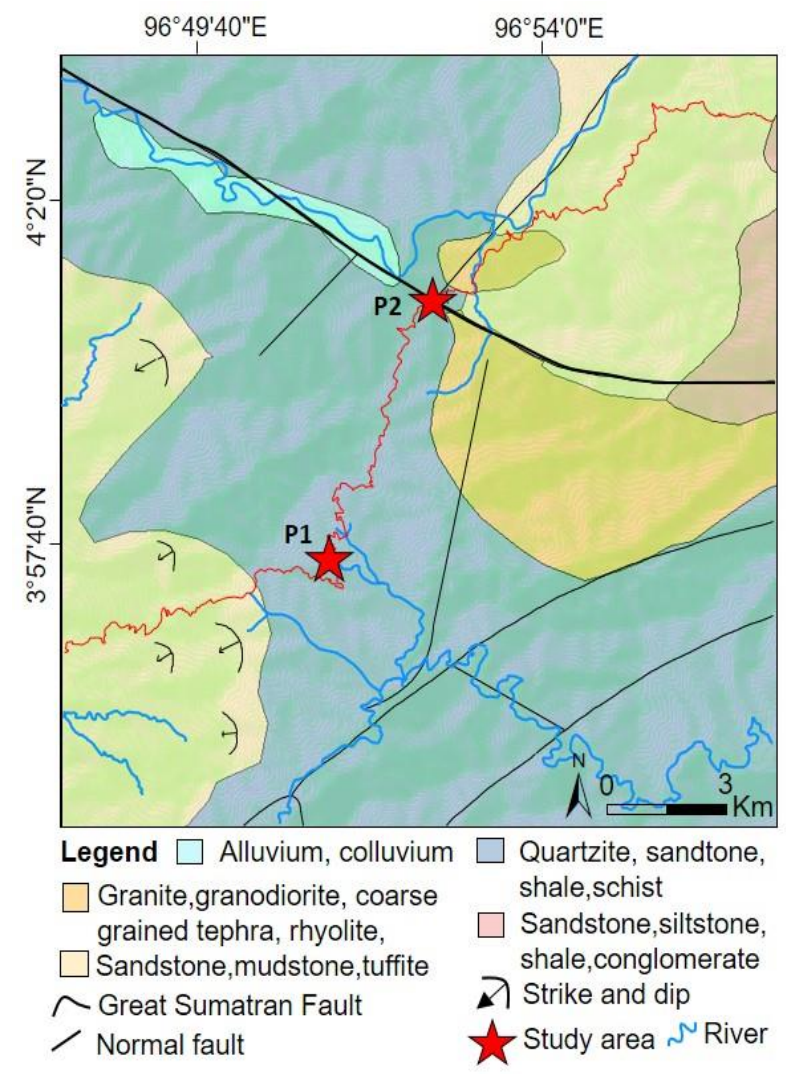

Fig.2: Geological map of the research area. The map describes the area dominated by sedimentaryrocks and the geological setting complex.

\section{Data and Methods}

In the study of the seismic refraction tomography method, the propagation of subsurface waves is used to describe the differences in the elasticity of the material in the landslide system [25]. The control source generates a mechanical wave that travels throughout the subsurface back to the surface with critical refraction when obtaining a contrasting impedance between two different mediums. This travel time is reversed to produce a model of the subsurface seismic velocity. $\mathrm{P}$ waves propagate on the subsurface at different speeds, which are influenced by physical and lithological properties. The $\mathrm{P}$ wave velocity is obtained from

$$
V p=\sqrt{\frac{K+\frac{4}{3} G}{\rho}}
$$

where $\mathrm{K}$ is the bulk modulus, $\rho$ is the density of the material, and $\mathrm{G}$ is the shear modulus.

In solid rock conditions, the relationship between seismic and wave saturation has been proven empirically. Given the condition of the rock saturated with liquid in the porous space replaced by gas, the $V_{p}$ value decreases rapidly. The relationship between these parameters and the physical properties of the rock can be used to determine the effect of saturation on the velocity of seismic wave propagation [30]. The humidity distribution in the soil structure and capillary force development on the pressure $\operatorname{affect}_{\mathrm{p}}$ on a small scale. Changes influence the decrease in Vp value in the soil matrix related to capillary force. Capillary influences tend to respond differently to each soil condition [31].

Measurement data on landslide studies with the SRT method was performed using Seismograph PASI 16S24-P developed by Italy's PASI Geophysics. Data acquisition was carried out using 24 geophones with 2 meter spacing between the geophones so that the SRT profile length was 92 meters. The study was conducted at two different locations, where profile 1 has a distance of $7 \mathrm{~km}$ with profile 2. Data measurements were performed using a $10 \mathrm{lbs}$. hammer source, where each profile has 9shotpoints. Each shotpoint is stacked 7 times in an attempt to get data with less noise. The travel time of the subsurface waves recorded on each geophone was modeled using the ZondST2D software. The first step of data analysis in seismic refraction is a picking wave to remove the noise that is affected by trigger transportation. Figure 4 is an example of a shot gather from profile 1 at a center shot. 

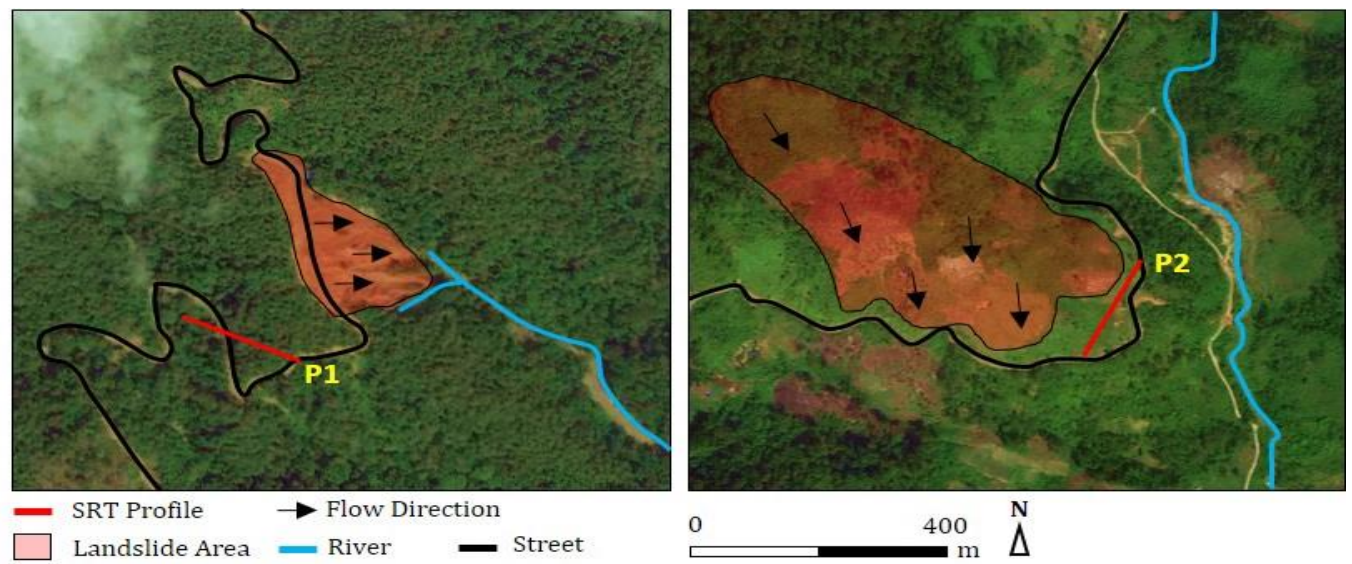

Fig. 3: Measurement design of the seismic refraction tomography method.

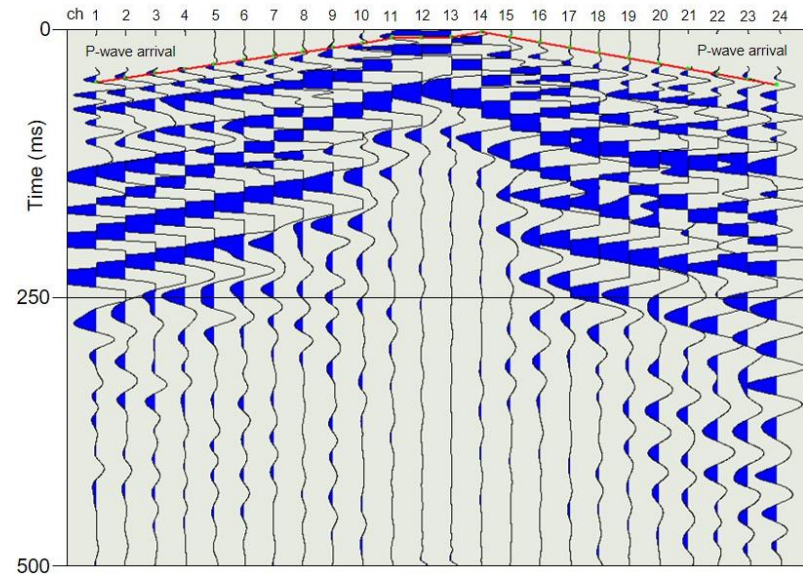

Fig 4.Example of shot gathers from profile 1 at a center shot. The red line is representing as direct P-wave arrival.

Data processing is used based on horizontal speed variations indicated by coarse topography. This method produces an initial velocity model through time-term inversion and minimizes the RMS value between the observed and calculated travel times. The model is obtained using the time-term method based on the linear least-square technique of data processing and subsurface modeling. For inversion problems, it is done by the Newtonian method using regularization. Regularization works by increasing the stability of the solution and producing a smoother speed distribution model.

$$
\left(A^{T} W^{T} W A+\mu C^{T}\right) \Delta m=A^{T} W^{T} \Delta f-\mu C^{T} R C m
$$

where $\mathrm{A}$ is a matrix of partial derivatives of the measured value of the part parameter (Jacobian), C is the smoothing operator, $\mathrm{W}$ is the matrix for measuring relative errors, $\mathrm{m}$ is the part parameter vector, $\mu$ is the regularization parameter, $\Delta \mathrm{f}$ is the difference vector between the observed and calculated values, $\mathrm{R}$ is the focusing operator [32]. The SRT data modeling can provide a P-wave propagation acceleration model that contrasts with the density of subsurface rocks. Besides, the model becomes a reference in the interpretation of the geometric characteristics of landslides.

\section{Results and Discussion}

The seismic refraction tomography data modeling results from the two study areas have an average wave velocity value of $0.2-2 \mathrm{~km} / \mathrm{s}$. The resulting SRT model is also able to describe in general the lithological boundary and subsurface geometry. The high sensitivity of $\mathrm{P}$ waves to conditions of rock heterogeneity, such as grain size, pores, cracks, or fractures in subsurface structures[33]. Simultaneously, there are also the same characteristics of the landslide system (Fig. 5). Meanwhile, the condition of the study site consists of rocks with high weathering rates and weak grain binding capacity dominating the area. The model obtained is compatible, where the value of the $P$ wave velocity is generally low.

Modeling data profile 1 obtains a 2D crosssectional model from the SRT method, which describes the subsurface structure consisting of three layers (Fig.6.a). P wave velocities distribution is generally relatively low in the near-surface area and relatively high at deeper depths.

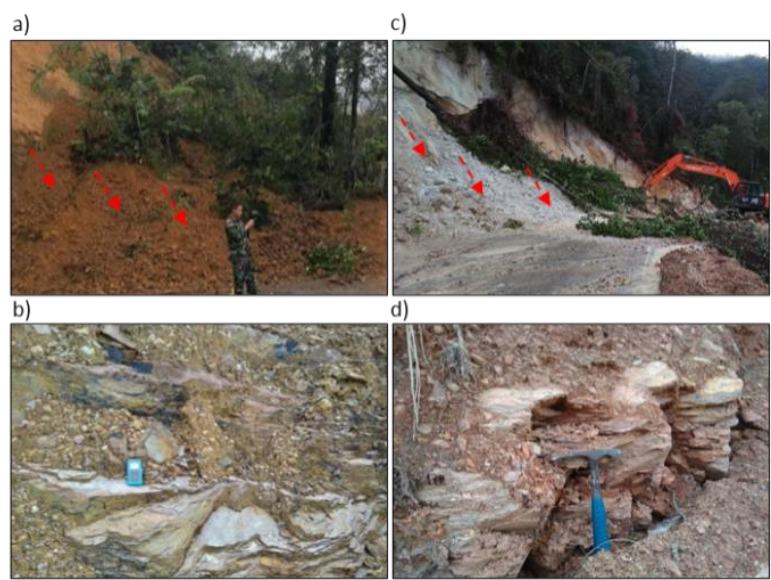

Fig. 5:The conditions at the site. a) Landslide conditions that have occurred in the study area profile 1,b) Rock structures in profile 1, c) Landslide conditions that have occurred in study area 2, d) rock structures in profile 2 .

The first layer with a depth of 0 - 8 meters at a profile length of 0-85 meters has a P-wave velocity 
value of $0.2-0.7 \mathrm{~km} / \mathrm{s}(200-700 \mathrm{~m} / \mathrm{s})$, which is interpreted as slate. The second layer with a depth of 8 - 16 meters and distributed along the profile has a Vp value of $0.8-1.3 \mathrm{~km} / \mathrm{s}(800-1300 \mathrm{~m} / \mathrm{s})$, which is interpreted as clay. In comparison, the third layer with a depth of 15 - 20 meters and distributed along the profile has a value of $1.4-1.9 \mathrm{~km} / \mathrm{s}$ (1400 $1900 \mathrm{~m} \mathrm{/s}$ ) interpreted as sandy clay. The lithological analysis of the rock type based on velocity data is also corresponded by another research such as in Xiaoshan District landslide site: Hangzhou, China [23], and Himalayan foothill region [24].

Meanwhile, SRT data modeling in profile 2 (Fig.6.b) obtained three subsurface layers based on the P-wave velocity.The P-wave velocity distribution is generally relatively low, where the near-surface layer has a relatively low value, and the deeper depth is relatively high.The first layer at a depth of 0 - 4 meters with a value of $0.5-1.0 \mathrm{~km} / \mathrm{s}$ (500 - 1000 $\mathrm{m} / \mathrm{s}$ ) is interpreted as a slate.The second layer with a depth of $4-12$ meters has a value of $1.1-1.6 \mathrm{~km} / \mathrm{s}$ $(1100$ - $1600 \mathrm{~m} / \mathrm{s})$, which is interpreted as clay.Meanwhile, the third layer at a depth of $12-20$ meters is interpreted as Sandy Clay, where the P wave velocity value ranges from $1.7-2.5 \mathrm{~km} / \mathrm{s}$ (1700 - $2500 \mathrm{~m} / \mathrm{s}$ ).

Both profile modeling can provide a contrasting description in response to the subsurface.On the other hand, model processing using ZondST2D allows the use of elevation changes that affect the resulting model.This is very helpful in the interpretation of the geometric model of the landslide system. Besides, the resulting model correlates with the topography and the distribution of near-surface rocks.
Based on the results of the P-wave velocity modeling results can be interpreted, profile 1 , which has a subsurface distribution of the surface with low porosity and is influenced by a steep topography.In profile 1 there is also a contrasting difference between the slate and clay (black line), which can be interpreted as a landslide plane (dotted line).Besides that, the slope impacts the formation of the sliding direction of the landslide material to have a significant landslide potential.Meanwhile, profile 2 with a steeper topographical condition has a greater level of potential for disaster than profile1.This can be seen from the contrasting difference between the layers of slate, clay, and sandy clay, which act as a landslide slide area (black line).The correlation between the slip plane and the topography forms the sliding direction of the landslide (dotted line).

The electrical resistivity from previous research consists of three layers: theslate rock at a depth of 0 10 meters, a clay in 10 - 35 meters, while a sandy clay layer performed at a 35 - 70 meters depth of [20]. In addition, the results obtained are able to describe the sediment boundary following the direction of the topographic settlement. These layers are also related to the elasticity of the rock material from velocity data.

The high sensitivity of the P-wave to the elastic properties of the subsurface medium with high porosity can describe the geometry of the landslide system clearly.This makes it possible to understand the mechanism of a landslide. Besides, modeling using elevation calculations provides a model correlated with field conditions, thus providing convenience in determining the model of the landslide system in an area.
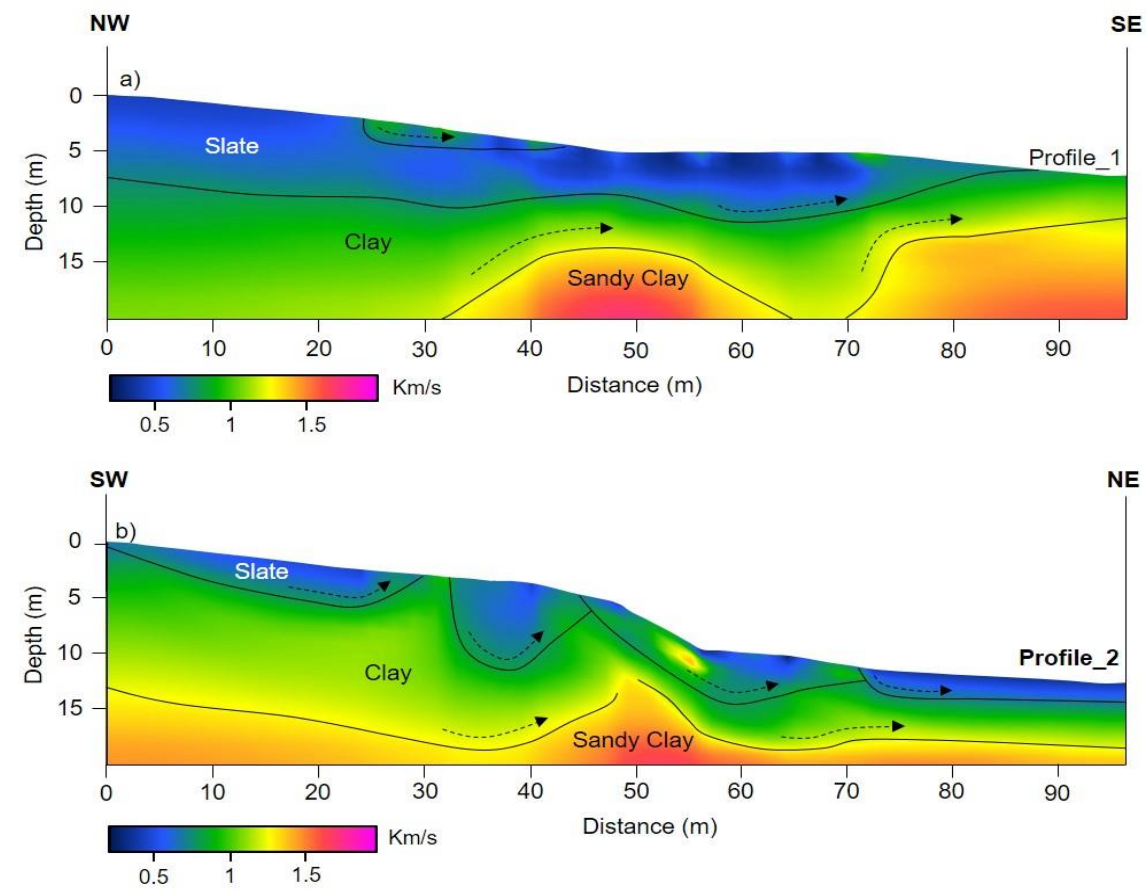

Fig.6: Seismic refraction tomography (SRT) model. a) SRT model of profile 1, b) SRT model of profile 2. 


\section{Conclusions}

The Babahrot - GayoLues road section is the main access for the community in carrying out economic activities in the central part of Aceh Province.The magnitude of the potential for landslides along these roads shows the importance of landslide mitigation efforts. The seismic refraction tomography method is used to provide fast and effective results.So that it is possible to be used to understand the mechanism of landslide disaster. Modeling from profile 1 obtains three subsurface layers where each layer boundary acts as a slip plane. This layer consists of slate $(0.2-$ $0.7 \mathrm{~km} \mathrm{/} \mathrm{s})$, clay (0.8 - $1.3 \mathrm{~km} / \mathrm{s})$, and sandy clay $(1.4-1.9 \mathrm{~km} / \mathrm{s})$.While the model obtained from profile 2, obtained three types of layers consisting of slate $(0.5-1.0 \mathrm{~km} \mathrm{/} \mathrm{s})$, clay $(1.1-1.6 \mathrm{~km} \mathrm{/} \mathrm{s})$, and sandy clay $(1.7-2.5 \mathrm{~km} / \mathrm{s})$. Where each layer acts as a slip plane. These results indicate that the SRT method can provide a good overview of the geometric boundaries of landslides.

\section{Acknowledgment}

We would like to thank Agus Hari Pramanaas a laboratory assistant and also for the geophysical studentwhohelped a lot in field observation research.

\section{References}

[1] D. Petley,"Global patterns of loss of life from landslides," Geology, (2012).

[2] R. Hidayat, S. J. Sutanto, A. Hidayah, B. Ridwan, and A. Mulyana,"Development of a landslide early warning system in Indonesia,"Geosci.,(2019).

[3] T. Dijkstra, N. Dixon, C. Crosby, M. Frost, D. Gunn, P. Fleming, et al.,"Forecasting infrastructure resilience to climate change,"Proc. Inst. Civ. Eng. Transp.(2014).

[4] S. Glendinning, P. Hughes, P. Helm, J. Chambers, J. Mendes, D. Gunn, et al.,"Construction, management and maintenance of embankments used for road and rail infrastructure: implications of weather induced pore water pressures," Acta Geotech.(2014).

[5] R. Huang andW. Li,"Formation, distribution and risk control of landslides in China," J. Rock. Mech. Geotech. Eng.(2011).

[6] Badan Nasional Penanggulangan Bencana,"Data Informasi Bencana Indonesia (DIBI)," Nopember 2018,(2018).

[7] J. Wasowski and F. Bovenga,"Investigating landslides and unstable slopes with satellite Multi Temporal Interferometry: Current issues and future perspectives,"Eng. Geol.,(2014).

[8] K. T. Chau, Y. L. Sze, M. K. Fung, W. Y. Wong, E. L. Fong, and L. C. P. Chan,"Landslide hazard analysis for Hong Kong using landslide inventory and GIS,"Comput. Geosci.,(2004).

[9] C. J. Van Westen, N. Rengers, and R. Soeters,"Use of geomorphological information in indirect landslide susceptibility assessment,"Nat. Hazards.,(2003).

[10] G. C. Ohlmacher,"The relationship between geology and landslide hazards of Atchison, Kansas, and Vicinity,"Curr. Res. Earth Sci.,(2000).
[11] R. Fell, J. Corominas, C. Bonnard, L. Cascini, E. Leroi, and W. Z. Savage,"Guidelines for landslide susceptibility, hazard and risk zoning for land use planning,"Eng Geol.,(2008).

[12] M. G. Angeli, A. Pasuto, and S. Silvano,"A critical review of landslide monitoring experiences," Eng. Geol., (2000).

[13] V. Pazzi, S. Morelli, and R. A. Fanti,"Review of the Advantages and Limitations of Geophysical Investigations in Landslide Studies,"Int. J. Geophys.,(2019).

[14] M. Yanis, M. Zainal, M. Marwan, and N. Ismail,"Delineation of Buried Paleochannel Using EM Induction in Eastern Banda Aceh, Indonesia. In: 81st EAGE Conference and Exhibition 2019 [Internet],(2019).

[15] M. Yanis, M. A. Bakar, and N. Ismail,"The Use of VLF-EM and Electromagnetic Induction Methods for Mapping the Ancient Fort of Kuta Lubok as Tsunami Heritage i,"23rd Europ. Meet. Env. Eng. Geophys.,(2017).

[16] M. Yanis, A. H. Pramana, F. Faisal, B. Bukhari, and N. Ismail,"VLF-R applications in landslides area: Case study from Paya Ateuk, South of Aceh,"Proc. Int. Conf. Nat. Env. Sci. (ICONES), 969,(2014).

[17] I. Rusydy, Ikhlas, B. Setiawan, M. Zainal, S. Idris , K. Basyar, et al.,"Integration of borehole and vertical electrical sounding data to characterise the sedimentation process and groundwater in Krueng Aceh basin, Indonesia,"Groundw Sustain Dev. Elsevier B.V.(2020).

[18] M. Marwan, R. Rifqan, I. Syafrizal, and Y. Muhammad,"Application of Vertical Electrical Sounding (VES) for Subsurface Profiling in Weh Island, Aceh Province,"Aceh Int. J. Sci. Technol., (2019).

[19] N. Ismail, M. Yanis, S. Idris, F. Abdullah, andB. Hanafiah,"Near-Surface Fault Structures of the Seulimuem Segment Based on Electrical Resistivity Model,"J. Phys.: Conf. Ser.,(2017).

[20] M. Zainal, B. Munir, and Marwan,"The electrical resistivity tomography technique for landslide characterization in Blangkejeren Aceh," J. Phys.: Conf. Ser.,(2021).

[21] Asrillah, D. Wahyuni, and U. Muksin,"The Correlation between P-Wave Velocity Value with Pathways of Geothermal Manifestation in the Area Ie Jue, Aceh Besar As Hazardous Side Study,IOP Conf. Ser.: Earth and Env. Sci.,(2019).

[22] J. S. Whiteley, J. E. Chambers, S. Uhlemann, J. Boyd, M. O. Cimpoiasu, J. L. Holmes, et al. "Landslide monitoring using seismic refraction tomography - The importance of incorporating topographic variations,"Eng. Geol.,(2020).

[23] P. Imani, G. Tian, S. Hadiloo, and A. A. ElRaouf,"Application of combined electrical resistivity tomography (ERT) and seismic refraction tomography (SRT) methods to investigate Xiaoshan District landslide site: Hangzhou, China," J. Appl. Geophys.,(2021).

[24] M. Israil and A. K. Pachauri,"Geophysical characterization of a landslide site in the Himalayan foothill region,"J. Asian Earth Sci., 22, 
3, 253-63, (2003).

[25] S. Uhlemann, S. Hagedorn, B. Dashwood, H. Maurer, D. Gunn, T. Dijkstra, et al.,"Landslide characterization using $\mathrm{P}$ - and S-wave seismic refraction tomography - The importance of elastic moduli,"J. Appl. Geophys.,(2016).

[26] U. Muksin, K. Bauer, M. Muzli, T. Ryberg, I. Nurdin, M. Masturiyono, et al.,"AcehSeis project provides insights into the detailed seismicity distribution and relation to fault structures in Central Aceh, Northern Sumatra,"J. Asian Earth Sci.,(2019).

[27] K. Sieh and D. Natawidjaja,"Neotectonics of the Sumatran fault, Indonesia,"J. Geophys. Res Solid Earth, 105, B12, 28295-326,(2000).

[28] Y. Muhammad, A. Faisal, A. Yenny, Z. Muzakir, M. Abubakar, I. Nazli,"Continuity of Great Sumatran fault in the marine area revealed by 3D inversion of gravity data,"J. Teknol.(2021).

[29] Z. Umar, B. Pradhan, A. Ahmad, M. N. Jebur, and
M. S. Tehrany,"Earthquake induced landslide susceptibility mapping using an integrated ensemble frequency ratio and logistic regression models in West Sumatera Province, Indonesia," Catena,(2014).

[30] M. A. Biot,"Theory of Propagation of Elastic Waves in a Fluid-Saturated Porous Solid. I. LowFrequency Range"J. Acoust. Soc. Am.,(1956).

[31] A. Romero-Ruiz, N. Linde, T. Keller, D. Or,"A Review of Geophysical Methods for Soil Structure Characterization,"Rev. Geophys.,(2018).

[32] A.E. Kaminskiy,"Program of two-dimensional seismotomography data processing and interpretation, User's Manual,Saint-Petersburg: ZondST2D softw, p. 1-20,(2013).

[33] M. Adelinet, C. Domínguez, J. Fortin, and S. Violette,"Seismic-refraction field experiments on Galapagos Islands: A quantitative tool for hydrogeology,"J. Appl. Geophys.,(2018). 